\title{
MARKETING CESTOVNÉHO RUCHU MESTA LIPTOVSKÝ MIKULÁŠ A OBCÍ MIESTNEJ AKČNEJ SKUPINY HORNÝ LIPTOV - JEHO REALITA A POTENCIÁL
}

\author{
Gréta Vrbičanová, Hilda Kramáreková
}

\begin{abstract}
Tourism is a thriving industry that brings economic benefits to the region and local authorities with long-term development potential. In order for tourism to become an important factor in the development of the economy, the legislative, institutional and program assurance from national to local level and its systematic marketing support are necessary. The phenomenon of electronic marketing of tourism opens new possibilities not only for tourism participants, but also for municipalities and municipality associations. Increased emphasis is put on innovative forms of promotion and creation of positive relationship between man and nature. The progressive development of the evaluation of cultural ecosystem services leads the society to sustainable development of the tourism. The aim of the paper is to point to the current state and potential of tourism marketing in the region of Liptov which has an international significance according to the Regionalization of the Tourism in the Slovak Republic and the categorization of tourism regions.
\end{abstract}

Keywords: e-marketing, strategy of tourism development, marketing communication tools

\section{Úvod}

Marketing, inovácie a cestovný ruch (CR) sú neodmyslitel’ným významným fenoménom moderného sveta, pričom ide o jedno z najdynamickejšie sa rozvíjajúcich odvetví hospodárstva $\mathrm{v}$ celosvetovom meradle. Marketing $\mathrm{CR}$ predstavuje súbor procesov zameraných na vytváranie a poskytovanie hodnoty vybraným ciel’ovým skupinám zákazníkov a na rozvíjanie vzt’ahov s nimi na lokálnej, regionálnej, národnej a medzinárodnej úrovni (Gúčik a kol., 2011). Proces globalizácie v súčasnosti spôsobuje, že regióny, mestá a obce si navzájom konkurujú v oblasti CR nielen na regionálnej, ale i národnej či medzinárodnej úrovni. Medzi novodobé konkurenčné výhody patria rôzne formy internetového marketingu (napr. zážitkový, obsahový, mobilný, video marketing, lovemarks) ako aj moderná marketingová komunikácia (e-mailing, newsletter) a sociálne siete (Facebook, Instagram, Twitter, YouTube). Tie podliehajú dôsledne pripravenej marketingovej stratégii $\mathrm{CR}$, ktorá ale ešte stále nie je bežnou súčastou strategických dokumentov samospráv alebo združení. Ciel'om príspevku je 
poukázat' na súčasný stav a potenciál marketingu CR v regióne Liptov, ktorý má podl'a Regionalizácie CR v Slovenskej republike a kategorizácie regiónov CR medzinárodný význam (Weiss a kol., 2005).

\section{Teoreticko-metodické východiská problematiky}

Cestovný ruch je v súčasnosti inštitucionálne zabezpečený na jednotlivých úrovniach nerovnomerne. Spolupráca kompetentných inštitúcií sa zlepšuje, avšak súčasný stav nevytvára optimálne riadenie efektívneho a úspešného rozvoja CR na všetkých úrovniach.

Pre Slovensko, člena Európskej únie, sú v oblasti udržatel'ného rozvoja záväzné na nadnárodnej úrovni viaceré strategické dokumenty (napr. Európa ako popredná svetová destinácia cestovného ruchu - nový politický rámec pre európsky cestovný ruch, Stratégia Európa 2020, www.europarl.europa.eu).

Na národnej úrovni legislatívne najviac súvisia so Zákonom č. 91/2010 Z. z. o podpore cestovného ruchu a Zákonom č. 281/2001 Z. Z. o zájazdoch, podmienkach podnikania cestovných kancelárií a cestovných agentúr. Inštitucionálne zabezpečenie marketingu $\mathrm{CR}$ na národnej úrovni patrí pod gesciu Ministerstva dopravy a výstavby SR, Sekciu CR, Odbor stratégie a analýz ako aj Odbor marketingu a propagácie. Medzi ich hlavné úlohy patrí zabezpečovanie tvorby a implementácia strategických a koncepčných materiálov rozvoja CR ako aj plnenie úloh v oblasti marketingu a propagácie SR ako turistickej destinácie (MDV SR, 2018). Aby mohol $\mathrm{v}$ destinácii fungovat' efektívny marketing $\mathrm{CR}$, musia všetky subjekty pôsobiace v oblasti CR úzko vzájomne spolupracovat', mat' jasne zadefinované kompetencie, zjednotenú marketingovú a komunikačnú stratégiu. Základnou úlohou marketingovej stratégie je určit’ opatrenia, na základe ktorých je možné dosiahnut' stanovený marketingový ciel' (MDV SR, 2013). V rámci programového zabezpečenia marketingu CR sú pre Slovensko záväzné dokumenty „Regionalizácia CR v SR (2005)“ a „Marketingová stratégia Slovenskej agentúry pre cestovný ruch na roky 2014 - 2020“, ktorá bola spracovaná na základe úlohy vyplývajúcej z dokumentu „Stratégia rozvoja cestovného ruchu do roku 2020“ z roku 2013. Ciel'om dokumentu je definovat' základné smerovanie marketingového pôsobenia Slovenska $\mathrm{v}$ oblasti $\mathrm{CR}$ na domácom a zahraničných trhoch. Medzi d’alšie strategické dokumenty možno zaradit' aj Národnú stratégiu rozvoja cyklistickej dopravy a cykloturistiky na Slovensku na roky $2013-2020$.

Kompetencie v oblasti CR na regionálnej úrovni patria v rámci Žilinského samosprávneho kraja pod Odbor informácií a zahraničných vzt’ahov, oddelenie CR a informácií. Programovo je CR zabezpečený prostredníctvom Stratégie rozvoja cestovného ruchu ŽSK pre roky 2007 - 2013. Strategickým dokumentov smerodajným pre CR je aj Územný generel CR ŽSK 2007 - 2013, PHSR ŽSK 2014 - 2020 a Cyklostratégia ŽSK 2014 s výhl'adom do roku 2025 (Región Žilina, 2018). Vel’mi výrazne sa na rozvoji CR Liptova podiel'ajú Oblastná organizácia 
CR Región Liptov (OOCR RL) a Klaster Liptov ako prvá oficiálna Organizácia destinačného manažmentu na Slovensku. Od vzniku tohto združenia právnických osôb (26 členov) je členom aj mesto Liptovský Mikuláš (LM), z Miestnej akčnej skupiny Horný Liptov (MAS HL) má členstvo Liptovský Hrádok a obec Smrečany. Svoje marketingové aktivity zameriava spolu OOCR RL na domáci aj zahraničný trh, zabezpečuje aktívnu propagáciu a e-marketing destinácie Liptov na webových stránkach a sociálnych siet’ach. OOCR RL zabezpečuje marketingovú stratégiu regiónu, regionálny produktový balík (Liptov Region Card), centrálny rezervačný systém ubytovania a marketingovú komunikáciu regiónu.

$\mathrm{Na}$ subregionálnej úrovni zasahujú do rozvoja CR mikroregióny, resp. MAS. V okrese LM je aktívnou okrem MAS HL (bez štatútu MAS) aj MAS Stredný Liptov. V aktuálnom programovom období 2014 - 2020 je pre MAS HL záväzný dokument CLLD stratégia rozvoja Horného Liptova 2014 - 2020 a pre MAS Stredný Liptov dokument Tvoríme rozvoj Stredného Liptova 2014 - 2020. V nich sa prioritne nezameriavajú na marketingovú stratégiu $C R$, ale na stanovenie špecifických ciel'ov a opatrení, ktoré by mali naštartovat' rozvoj CR územia.

Na lokálnej úrovni je zodpovedným orgánom koordinácie CR mesto, resp. obec. V meste LM koordinuje CR v rámci mestského úradu Oddelenie marketingu a podnikania, ktoré spolupracuje $s$ Informačným centrom mesta a OOCR RL pri tvorbe a propagácii produktov CR. Podiel'a sa na tvorbe a implementácii koncepcie rozvoja CR mesta, marketingovej a komunikačnej stratégii, ktoré sú súčastou Programu hospodárskeho a sociálneho rozvoja mesta (PHSR) Liptovský Mikuláš na roky 2015 - 2022.

V odbornej literatúre, či už domácej alebo zahraničnej proveniencie, sa marketingu $\mathrm{CR}$ zaoberá množstvo domácich a zahraničných autorov. V rámci Slovenska možno uviest' práce napr. Gúčik a kol. (2011), Nemčíková a kol. (2016), zo zahraničia napr. Wang et al. (2002), Palatková (2006), Jakubíková (2012). Novému trendu elektronického marketingu, ktorý zahŕňa internetový (webový) marketing, mobilný marketing, position marketing (marketing prostredníctvom GPS, auto-navigácie) a on-line televíziu, sa venujú autori napr. Ungr et al. (2014) a Dorčák (2012). Vplyvom e-marketingu na rozvoj vidieckej krajiny sa zaoberali Beresecká (2012) alebo Andreopulou et al. (2014). Marketing CR na sociálnych sietach je predmetom výskumu autorov Rathore et al. (2017), Xiang, Gretzel (2010), resp. Lin, Huang (2006). Propagácii ako nástroju marketingu miestnej akčnej skupiny sa venoval Tigyi (2016), budovaniu značky regionálneho produktu Kramáreková a kol. (2018). Marketingu CR a jeho marketingovej komunikácii sa na lokálnej úrovni venovali Palenčíková - Hrubalová (2016) či Krogmann a kol. (2014, 2016). Myšlienku presadit' hodnotenie ekosystémových služieb v marketingu a manažmente území, ktoré sú poznačené vplyvom CR, presadzujú autori Eliáš (2010), Getzner - Švajda (2015) alebo Považan (2013). 


\section{Vymedzenie záujmového územia}

Predmetnú problematiku študujeme na spoločnom území mesta Liptovský Mikuláš a MAS Horný Liptov (obr. 1).

Obr. 1: Poloha mesta Liptovský Mikuláš a MAS HL v rámci Slovenskej republiky Figure 1: Area of the city of Liptovský Mikuláš and LAG Horný Liptov in the Slovak Republic

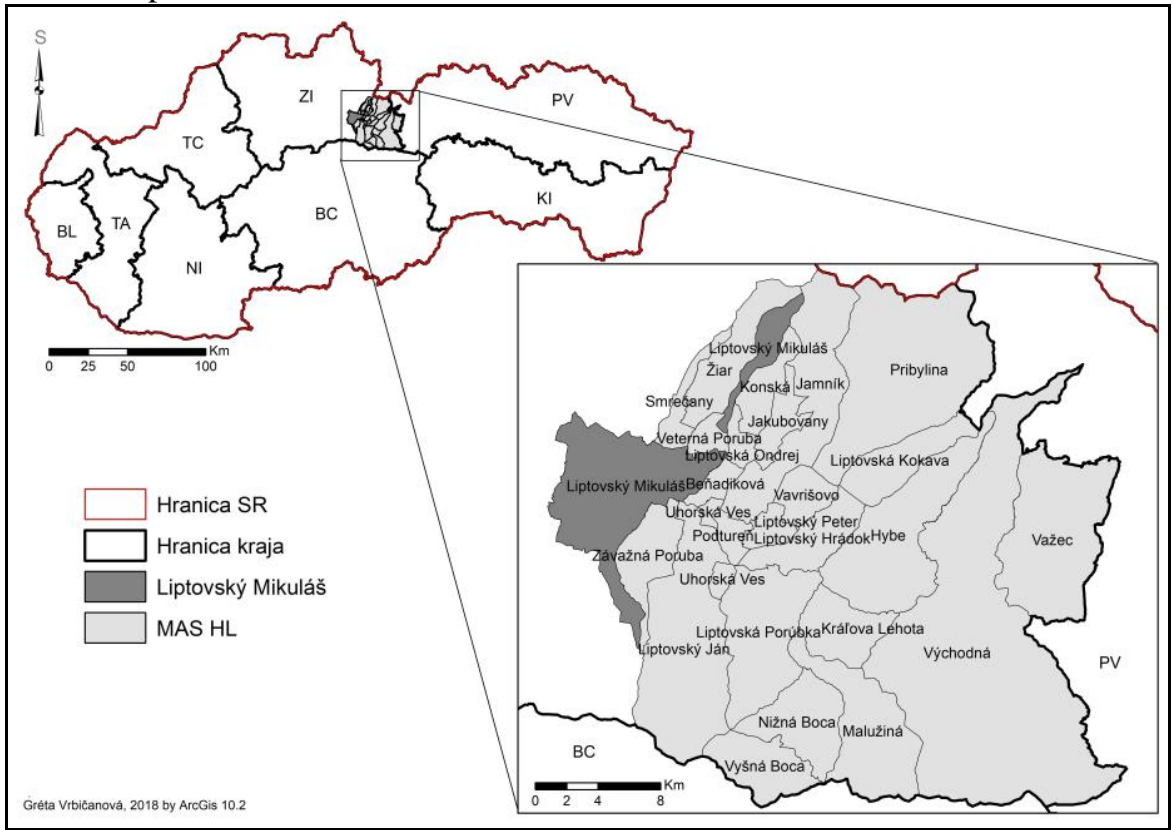

Mesto Liptovský Mikuláš (LM) je situované v severnej časti stredného Slovenska, v juhovýchodnej časti Žilinského samosprávneho kraja. Územie sa rozprestiera na východe Liptovskej kotliny, z južnej strany je lemované pohorím Nízke Tatry, zo severnej strany obklopené pohorím Západné Tatry a Chočskými vrchmi na severozápade. Mesto sa rozprestiera prevažne na pravom brehu rieky Váh, ktorá sa na západnom okraji intravilánu vlieva do vodnej nádrže Liptovská Mara. Nachádza sa v centrálnej časti okresu Liptovský Mikuláš, ktorého je hospodárskym, kultúrnym a turistickým centrom (strediskom). Najstarší písomný záznam o LM je z roku 1286 v listine král'a Ladislava IV., kde sa mesto spomína ako „possessio Scentmiklos“ vo vlastníctve Pongrácovcov, ktorí ho vlastnili aj v nasledujúcich storočiach. Svätý Mikuláš (súčasný LM) sa formoval postupne z farskej usadlosti, ktorá tu vznikla s výstavbou Kostola sv. Mikuláša. Ten má v 
dejinách mesta obzvlášs' významné postavenie. Svedčí o tom i skutočnost', že názov sídla je totožný s menom duchovného patróna kostola (Kufčák a kol., 1968). Administratívne sa mesto v roku 2018 člení na 16 mestských častí, ktoré sa rozprestierajú na 11 katastrálnych územiach. Počas uplynulých 10 rokov má vývoj počtu obyvatel'ov v meste LM klesajúcu tendenciu, k 31. 12. 2017 dosiahol 31345 obyvatel'ov (ŠÚ SR, 2018).

Miestna akčná skupina Horný Liptov (MAS HL) je situovaná v juhovýchodnej časti okresu Liptovský Mikuláš v Žilinskom kraji. Územie sa rozprestiera na východe Liptovskej kotliny, z južnej strany je lemované pohorím Nízke Tatry a zo severnej strany obklopené pohorím Vysoké a Západné Tatry. Najvýznamnejším vodným tokom $\mathrm{v}$ tejto oblasti je Váh, ktorý preteká stredom územia MAS HL. Územie tohto združenia hraničí na severe s Pol'skom, na východe susedí s okresom Poprad a na juhu s okresom Brezno.

Myšlienka spojenia obcí Horného Liptova so zámerom systematickej spolupráce na rozvoji vznikla v roku 2007. Do verejno-súkromného partnerstva vstúpilo v roku 2008 dokopy 21 obcí (Vyšná Boca, Nižná Boca, Malužiná, Král'ova Lehota, Liptovská Porúbka, Podtureň, Liptovský Ján, Uhorská Ves, Beňadiková, Liptovský Ondrej, Konská, Jakubovany, Jamník, Pribylina, Liptovská Kokava, Vavrišovo, Liptovský Peter, Hybe, Východná, Važec, Závažná Poruba) a mesto Liptovský Hrádok. O 6 rokov neskôr aj Veterná Poruba, Smrečany a Žiar. Týchto 25 obcí predstavuje $800,77 \mathrm{~km}^{2}(59,7 \%$ územia okresu LM, počet obyvatel'ov k 31. 12. 2017 dosiahol 27666 (Š́́ SR, 2018).

Aj ked' prvý krát štatút MAS získala v roku 2009, Pôdohospodárska platobná agentúra na konci roka 2017 tomuto verejno-súkromnému partnerstvu opätovný štatút MAS z programu Rozvoja vidieka SR 2014 - 2020 neschválila. V súčasnosti má členstvo v združení 25 obcí, 12 právnických osôb a 18 fyzických osôb. Centrom územia MAS HL je mesto Liptovský Hrádok, ktorý má spolu s okolitými obcami bohaté historické tradície, ale aj prírodné bohatstvo. Tie je potrebné prostredníctvom MAS HL rozvíjat', udržiavat' a zhodnocovat' (Vrbičanová, Kramáreková, 2016).

\section{Marketing cestovného ruchu vo vymedzenom území}

Mesto Liptovský Mikuláš má marketingovú stratégiu CR vypracovanú v rámci aktuálneho PHSR 2015 - 2022. Zameriava sa na rozvoj mestského CR a budovanie príslušnej infraštruktúry $\mathrm{CR}$ ako aj na podporu oživenia historického centra a jeho zatraktívnenie pre návštevníkov a turistov (napr. podporovat' otvorenie prevádzok s tradičnými výrobkami, suvenírmi, či reštauračné zariadenia s otvorenými terasami). Dôraz, aký kladie mesto na význam CR, sa pozitívne odzrkadlil v priebehu minulého roka 2017, kedy dostalo ocenenie NAJ mesto Slovenska 2017, v rámci sút’aže organizovanej informačným portálom SLOVAKREGION.SK, do ktorej sa hlasovaním zapájala široká verejnost' zo 
Slovenska a zahraničia. Nosnou čast’ou marketingovej stratégie mesta je vytýčenie najväčších problémov, ktorým treba podriadit' plánované projekty a vízie rozvoja. Nežiaducimi javmi sú nedostatok atraktívnych produktov počas zimnej turistickej sezóny, možností trávenia vol'ného času pre rodiny s det'mi, oddychových zón, parkovacích plôch v blízkosti centra i nedostatočnú koordináciu termínov podujatí.

Na území MAS HL bolo v predchádzajúcom programovom období 2007 2014 vyhlásených 6 výziev z Programu rozvoja vidieka (PRV) SR pre opatrenie podpory činnosti v oblasti vidieckeho $C R$, pričom sa úspešne zrealizovali 4 projekty $(6,1 \%$ zo všetkých 66 projektov MAS HL). Do oblasti rekonštrukcie ubytovacích zariadení boli zapojené 2 projekty (7,4 \% zo všetkých podporených 66 projektov združenia) (Vrbičanová, Kramáreková, 2016). Skutočnost', že sa na území MAS HL podarilo zrealizovat' iba taký nízky počet projektov, svedčí o neúplnej zaangažovanosti sa jednotlivých subjektov na území združenia, resp. nezáujme rozvíjat' $\mathrm{CR}$ na území a aj chýbajúcej marketingovej stratégii $\mathrm{CR}$. Stratégia CLLD MAS HL do r. 2020 zmieňuje fakt, že územie má vel'ké rezervy v oblasti marketingu CR (MAS HL, 2015a). V Spoločnom PHSR obcí Horného Liptova do r. 2022 je tak isto uvádzaná skutočnost', že rozvoj CR brzdí neprepojenost' atraktivít na území MAS HL, chýbajúca koordinácia, spolupráca, propagácia, nedostatočný informačný systém a nízka úroveň služieb (MAS HL, 2015b). Aj napriek tomuto poznatku v oboch strategických dokumentoch absentuje marketingová a komunikačná stratégia CR. MAS HL sformulovala v CLLD stratégii zámer, ktorého ciel'om je podporit' rozvoj služieb v oblasti CR so zameraním najmä na turistickú klientelu, ktorá môže byt' zdrojom zamestnanosti vidieckeho obyvatel'stva. Vyššia pozornost' CR je venovaná v Spoločnom PHSR obcí Horného Liptova do r. 2022. Všetkých 25 obcí definovalo v tomto dokumente indikatívne aktivity pre opatrenie Budovanie infraštruktúry CR v obci v celkovom počte 160. Najväčší dôraz na CR je kladený v obci Hybe (16 aktivít), Liptovský Hrádok (13), Pribylina (16) a Žiar (15). Najmenej aktivít z tohto opatrenia je plánovaných do roku 2020 v obci Liptovský Peter (1), Uhorská Ves (2), Beňadiková (2) a Vyšná Boca (3). V rámci opatrenia Posilnenia marketingu obcí a regiónu prevažovali aktivity zamerané na budovanie informačno-náučných turistických trás a podporu prezentačných a propagačných aktivít (spolu 37 plánovaných aktivít). Rozvíjat' túto oblast' považuje za potrebné obec Nižná Boca (6 aktivít), Vyšná Boca (5) a Žiar (6). Žiadne aktivity v oblasti marketingu obce ako takej alebo CR na jej území neboli hlásené v 10 obciach (MAS HL, 2015b).

\section{Aktuálny stav marketingovej komunikácie vo vymedzenom území}

V súčasnosti sa postupne začína ustupovat' od využívania klasickej formy propagácie CR, ako brožúry, katalógy, plagáty či letáky. Elektronický marketing sa stáva čoraz významnejšou formou propagácie, tento nový, stále sa rozrastajúci druh marketingu, má množstvo neustále sa vyvíjajúcich a pribúdajúcich foriem, 
ktoré sú schopné pokryt' väčšinu ciel'ových skupín. Vzhl’adom na široké spektrum možností trávenia vol'ného času na území mesta LM ako aj MAS HL počas celého roka, je hlavným nedostatkom ich potenciálu slabá propagácia a marketingová komunikácia.

Nástroje marketingovej komunikácie CR mesta Liptovský Mikuláš vychádzajú z dodržiavania jednotnej a aktuálnej komunikačnej stratégie, ktorá je súčast'ou marketingovej stratégie v PHSR mesta LM 2015 - 2022. Ciel'ovými skupinami návštevníkov mesta LM sú rodiny s det’mi (deti majú prázdniny viackrát do roka), seniori, návštevníci hl’adajúci aktívne strávenie vol’ného času so športovým zameraním a školské výlety. Priemerne strávia jednotlivé ciel'ové skupiny v meste a v okolí tri dni. Ciel'om je motivovat' ich na dlhší pobyt alebo na strávenie druhej dovolenky. Medzi kl'účové marketingové nástroje mesto Liptovský Mikuláš zarad'uje prezentáciu produktov a subjektov $\mathrm{v}$ CR na internetovej stránke mesta (www.mikulas.sk; obr. 2) a na sociálnych siet'ach Facebook a Twitter (obr. 3). Tu sú zverejňované informácie z diania v meste vo forme pozvánok na podujatia, či informácie a fotodokumentácia renovácií verejných priestorov, alebo iných projektov realizovaných na území mesta. Pravidelne je zverejňované najnovšie číslo mesačníka Mikuláš, ako aj vysielanie TV Liptov - Liptovské noviny, ktorého poslaním je informovanie obyvatel'ov najmä mesta. Medzi d’alšie nástroje patrí newsletter a mobilná aplikácia „Liptovský Mikuláš“ (obr. 2).

Obr. 2: Internetová stránka mesta LM a mobilná aplikácia Liptovský Mikuláš Figure 2: Web page of the city LM and mobile app Liptovský Mikuláš
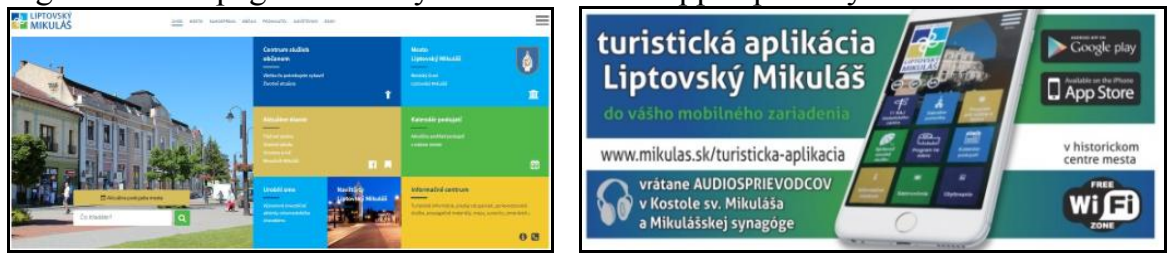

Obr. 3: Profil mesta LM na sociálnej sieti Facebook a Twitter (2018)

Figure 3: Facebook and Twitter account of the city of LM (2018)
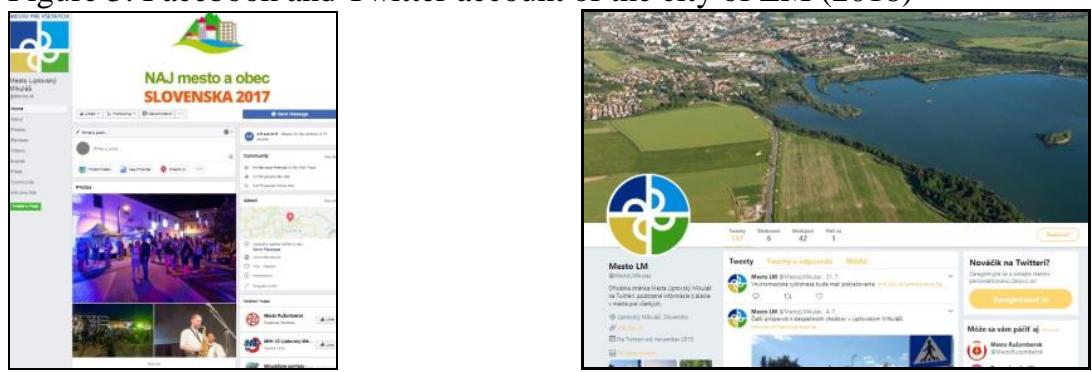
Tak isto je kladený dôraz aj na prípravu kvalitných propagačných materiálov (každoročne by mal byt' vytvorený bezplatný propagačný materiál, určený na reprezentáciu a výstavy), 2 produktové materiály s aktuálnou ponukou mesta na letnú a zimnú turistickú sezónu, jednoduché letáky k produktom, kalendár podujatí + bedeker. Ciel'om stratégie CR je využit' potenciál regiónu a prilákat' návštevníkov z okolitých stredísk do mesta. Propagácia mesta prebieha v rámci jeho územia aj prostredníctvom billboardov, značení, navigačných a informačných tabúl' pre turistov. Významne mestský CR propaguje Informačné centrum mesta $L M$ formou propagačných materiálov (brožúry, letáky, pohl'adnice, magnetky, odznaky, perá) ale aj sprievodcovskými službami. Aktívne vystupuje na sociálnej sieti Facebook a Instagram (obr. 4), kde sú uverejňované pozvánky na podujatia, fotografie a videozáznamy. Na sociálnej sieti Facebook sú aktívne aj jednotlivé mestské časti, kde sú uverejňované pozvánky na podujatia alebo fotografie zo svojho okolia.

Obr. 4: Profil Informačného centra mesta LM na sociálnej sieti Facebook a Instagram (2018)

Figure 4: Facebook and Instagram account of the Information Centre of the Town LM (2018)
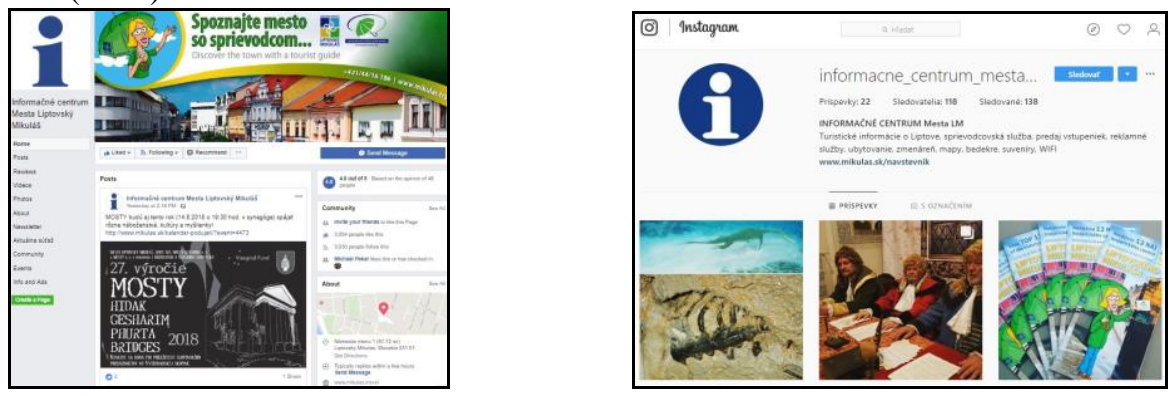

Za hlavný marketingový nástroj MAS HL je možné považovat' internetový portál združenia www.hornyliptov.sk (obr. 5). Uverejňované sú pozvánky na akcie v obciach združenia (posledná z roku 2016) a informácie týkajúce sa samotnej MAS HL (napr. realizácia projektov). V priebehu roku 2017 nevyvíjala MAS HL na tejto stránke žiadnu propagačnú ani informačnú činnost'. Momentálne je možné (na základe iba 2 oznamov uverejnených na stránke združenia v priebehu prvého polroka 2018) zhodnotit' marketingovú komunikáciu ako nedostatočnú. MAS HL nefiguruje ani na jednej zo sociálnych sietí. V roku 2011 vydala MAS HL propagačné materiály v rozsahu dvoch strán 23 obciam zo združenia (okrem obcí Veterná Poruba, Smrečany a Žiar, ktoré v tom čase členmi MAS neboli). V roku 2018 propagačné materiály pre tieto obce uverejnené medzi ostatnými $\mathrm{v}$ online verzii na stránke združenia ešte stále neboli. Informačný 
spravodaj MAS HL č. 1 z roku 2014 je uverejnený v archíve internetovej stránky MAS HL. V printovej podobe boli výtlačky umiestnené aj na obecných úradoch obcí zo združenia. Hlavnou témou boli informácie o činnosti a realizácií aktivít v rámci Integrovanej stratégie rozvoja Horného Liptova do roku 2015. Ďalšie vydania už neboli zrealizované. Propagácia činnosti MAS HL bola podl'a poslednej výročnej správy z marca 2015 realizovaná aj prostredníctvom printových médií (obecné spravodaje, priebežne v týždenníku MY Liptov, stolový kalendár na rok 2014 a iné reklamné predmety). Prezentácia na internete je uvádzaná na portáli YouTube vo forme video vizitky územia (MAS HL nemá vytvorený samostatný profil), ktorá vznikla v rámci projektu „Podpory CR - Horný Liptov“ (v r. 2014 vd'aka podpore PRV SR 2007 - 2014) súčasne aj s mal'ovanou mapou Horného Liptova a mobilnej aplikácie Liptov Guide (pre iOS a Android). Ako komplexný informačný systém, využitel'ný pre potreby marketingu vidieckeho cestovného ruchu, bola $\mathrm{v}$ rámci projektu Regionálny elektronický informačný systém prostredníctvom Združenia ubytovatel'ov Tatier vytvorená internetová stránka www.hornyliptov.eu (obr. 5). Finančne bol projekt podporený z Programu rozvoja vidieka Slovenskej republiky v roku 2013. Naposledy bola stránka aktualizovaná v roku 2014 (stav ku dňu 3. 8. 2018). Nie sú propagované podujatia organizované v jednotlivých obciach ani v širšom okolí územia. Tým jej pôvodná myšlienka naštartovat' propagáciu, opätovne upadá (Vrbičanová - Kramáreková, 2016).

Obr. 5: Internetová stránka MAS HL a stránka informačného systému (2018) Figure 5: Web page of the LAG HL and page of the information system (2018)
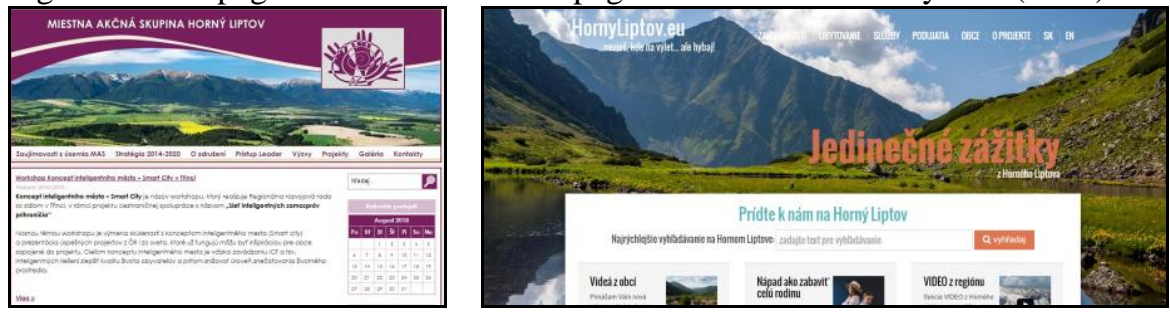

Na svojom území nemá MAS HL informačné tabule, ktoré by informovali obyvatel'ov či turistov o pôsobení združenia na tomto území. Prepojenie na internetovú stránku združenia majú len 3 obce z 25 (Liptovský Peter, Nižná Boca a Žiar). Vlastná internetová stránka MAS HL priamu možnost' prepojenia na stránky obcí zo združenia neponúka.

\section{Potenciál nových stratégií v marketingu $C R$ vo vymedzenom území}

Uplatnenie nových stratégií $\mathrm{v}$ marketingu $\mathrm{CR}$ má (nielen) v našom vymedzenom území značný potenciál. 
Zážitkový marketing (event marketing) predstavuje účinný nástroj ako pretavit' stanovené strategické marketingové ciele na komunikáciu osobným a nezabudnutel'ným spôsobom, ktorý zanechá v návštevníkovi intenzívny zážitok. $V$ rámci CR to môžu byt' zážitkové hotely, nakupovanie, turistika alebo zážitková gastronómia. Vzhl'adom na to, že sa Liptov vyznačuje špecifickou kuchyňou a na území sú už známe viaceré lokálne podujatia (napr. Pribylina - Sútaž vo varení bryndzových halušiek, v rámci LM Švábkafest, na úrovni mestských častí Liptovská Ondrašová - Ondrašovská fazul'a, Il'anovo - Fašiangová dedinská zabíjačka) by mohlo byt' podnetné pre MAS HL organizovanie gastrofestivalu, ktorého predmetom by bola sút’až vo varení typických jedál medzi všetkými 25 obcami zo združenia, sprevádzaná tradičnou ukážkou prípravy jedál, sútažou o najlepší recept z každej obce, kultúrnymi tradíciami (folklór) či športovými atrakciami a stánkovým predajom lokálnych suvenírov z remeselníckej výroby. Ked’že by to bolo unikátne podujatie, ktoré sa v takom rozsahu na území Horného Liptova neorganizuje, prilákalo by nie len miestnych obyvatel'ov, ale aj turistov.

Ďalšou formou zážitkového marketingu by mohli byt' záăitkové interaktívne hry. Na základe histórie regiónu by mohli byt' vytvorené legendárne postavy, ktorých príbeh sa viaže ku konkrétnym miestam záujmu (napr. inscenácia bojov SNP). Prioritne by bolo vhodné zapojit' atraktivity (napr. lokalita vrchu Slemä s náučným chodníkom SNP a troskami lietadla v obci Liptovská Porúbka), následne môžu byt' súčast'ou poznávacej hry aj ostatné zariadenia (stravovacie, ubytovacie, pamätníky SNP - napr. Háj Nicovô v LM), ktoré turisti navštívia. Ciel'om by bolo zbierat' pamiatkové predmety, napr. nálepky, náramky, odznaky a pod. Na obdobnom princípe funguje zberatel'ská hra pre deti Agharta, do ktorej sú zapojené turistické lokality Jánska dolina, Liptovský Ján, Žiar a Podbanské (www.agharta.sk). Novinkou leta 2018 je hra pre deti organizovaná Klastrom Liptov - Liptoviedky (https://www.visitliptov.sk/liptoviedky).

K d'alším novodobým trendom marketingu v CR patrí obsahový marketing (content marketing), ktorý sa teší stúpajúcej popularite od roku 2011. Je to marketingová technika, pri ktorej sa vytvára a zdiel’a hodnotný, relevantný obsah za účelom zaujat' a získat' si publikum - to všetko s ciel'om dosiahnut' takú reakciu zákazníka, ktorá prinesie zisk, návštevníkov do danej destinácie. Medzi najpoužívanejšie techniky content marketingu patria napr. infografiky, webstránky, videá, (e)knihy, blogy, aplikácie či prezentácie. Integrálnou súčast’ou by mali byt' aj sociálne siete, kde je vytvorený obsah zdiel'aný (social media content). Najlepší content marketing má vzdelávací charakter, nie predajný (Čakloš, 2017). Ako obsahový marketing MAS HL možno považovat' videovizitku z roku 2011, ktorá zachytáva turisticky atraktívne destinácie v jednotlivých obciach. Jej hlavným problémom je absentujúca propagácia videa a skutočnost', že nerozvíja video marketing prostredníctvom tvorby d'alších náučno-informačných videí. Naštartovat' obsahový marketing by združeniu pomohla kvalitnejšie spracovaná internetová stránka s prepojením na sociálne siete (Facebook, Instagram), na 
ktorých by boli zdiel'ané napr. geografické alebo historické informácie z územia. Na základe prieskumu cez sociálne siete by bolo združenie schopné identifikovat' lokality, ktoré sú pre návštevníkov či obyvatel’ov atraktívne a začlenit' ich do náučných chodníkov, návrhov osadenia lavičiek, budovania rozhl'adne. Na rozdiel od združenia, mesto LM aktívne informuje návštevníkov vlastnej internetovej stránky, on-line mesačníka ako aj prostredníctvom sociálnych sietí o histórii mesta, podujatiach a možnostiach trávenia vol'ného času. Obyvatelia sú aktívne zapájaní do diskusie a mesto reaguje na ich podnety. Video marketing obdobne ako v prípade MAS HL nie je podporovaný, vytvorené bolo doposial' len jedno video, v ktorom je obsiahnutá ponuka služieb Informačného centra mesta LM. Obsahový marketing by zdokonalil blog mesta, kde by boli uverejňované tipy na výlety v meste a jeho blízkom okolí od návštevníkov, poslancov či vedenia mesta so zaujímavými postrehmi, radami, odporúčaniami (napr. na stravovanie, ubytovanie, výhl'ady, možnosti opekania si, piknikov). Pravidelne by sa mohli konat' tematické sút'aže o najkrajšiu fotografiu, originálne opísané zážitky z výletu, ktoré by vd’aka zaujímavým výhram (zl’avové kupóny využitel'né v meste, bezplatné vstupy do múzeí, galérií, lyžiarskeho strediska či kúpaliska) motivovali l'udí skúmat' mesto a jeho okolie. Vzhl'adom na prítomnost' niekol'kých chránených lokalít na vymedzenom území by sa mal marketing zameriavat' aj na šírenie povedomia o potrebe chránit' tieto ekosystémy, pretože poskytujú nespočetné množstvo kultúrnych ekosystémových služieb (napr. turistika, estetika krajiny, pozorovanie divo žijúcich živočíchov, rastlinstva, duchovné vyžitie, vzdelávanie). Slabou stránkou spoločnosti je, že si význam prírody začne obvykle uvedomovat' až vtedy, ked' pocit'uje nedostatok úžitkov, ktoré mu poskytovala (Eliáš, 2010). Toto tvrdenie sa obzvlášt' dotýka kultúrnych ekosystémových služieb, ktoré je vel'mi t’ažké, dokonca často i nemožné nahradit'. Pritom tieto úžitky z ekosystémov predstavujú neodmyslitel'nú súčast' $\mathrm{CR}$, ktorý sa im nie vždy priaznivo odpláca. Presadzovat' by sa mal obsahový marketing zameraný na ekoturizmus a agroturistiku ako šetrné formy CR v l'ahko zranitel'nom území.

Lovemarks marketing (www.lovemarkscampus.com) je založený na emocionálnom vzt’ahu návštevníkov k danej lokalite či značke. Smeruje k tomu, aby bola daná značka či destinácia medzi zákazníkmi preferovaná. Táto marketingová teória stojí na poznatku, že emócie hýbu l’udí k činom, zatial' čo racionálne argumenty im vytvárajú v hlavách závery. Na území Liptova je silnou lovemark značkou turizmu Klaster Liptov - Liptov treba zažit'. Mesto LM spolu s Liptovským Hrádkom a obcou Smrečany (z MAS HL) získavajú z členstva v klastri výhody nepretržitej a modernej propagácie, ktorá na ich územie láka turistov počas celého roka. Vzhl'adom na to, že MAS HL má také slabé zastúpenie obcí v klastri, svedčí o skutočnosti, že obce nemajú záujem spolupracovat' na rozvoji CR, resp. nie je to medzi ich prioritami. Podporovat' by ich v tomto kroku mala samotná MAS HL, ktorá by mohla následne čerpat' z prílivu turistov a rozvíjat' tak nie len povedomie o potenciáli CR na území (hlavne vidiecky 
turizmus, agroturistika a ekoturizmus), ale sa aj aktívne zapájat' a spolupracovat' v propagácii a v získavaní sponzorov.

V súčasnosti môžeme pozorovat', že spoločnost' sa čoraz viac presúva od používania klasických stolových osobných počítačov $\mathrm{k}$ používaniu smartfónov a abletov, $\boldsymbol{k}$ mobilnému marketingu. V destinácii $\mathrm{CR}$ môže návštevník prostredníctvom takýchto aplikácií získat' informácie o ciel'ovom mieste $\mathrm{v}$ reálnom čase, kedy sa tam nachádza. Dôležitým faktorom je ich unikátnost', originalita a propagácia aplikácie napríklad prostredníctvom webstránok a sociálnych sietí (Ungr a kol., 2014). Mesto má vytvorenú mobilnú aplikáciu s audiosprievodcom pre všetky historické pamiatky koncentrované v centre mesta. Užívatel'om formou upozornení oznamuje nastávajúce podujatia v meste alebo špeciálne akcie. Aktívne je propagovaná na internetovej stránke mesta, sociálnej sieti Facebook, ako aj prostredníctvom Facebook profilu Informačného centra mesta. Mobilná aplikácia, ktorá vznikla v spolupráci MAS HL a OZ dobrej vôle, Liptov Guide, nenaplnila svoje očakávania. V súčasnosti je dostupná len pre iOS v neaktualizovanej verzii z roku 2014, s chýbajúcimi kontextovými prepojeniami na kontakty atrakcií, chybne zaznačenými objektmi v mape či nedoplnenými podujatiami organizovanými na území. Preto sa združeniu MAS HL otvára možnost' opätovne projekt mobilnej aplikácie obnovit' a aktualizovat', resp. vytvorit' novú aplikáciu. Jej súčast'ou by okrem bežných turistických trás boli lokality, ktoré nie sú žiadnou inou formou propagované, napr. miestne farmy s priamym predajom mlieka (napr. v Liptovskej Porúbke), odpočívadlá s lavičkami s výhl’adom na Kriváň (Liptovská Kokava), možnosti stanovania (Pribylina) alebo lokálne podujatia (splav rieky Váh v Liptovskej Porúbke).

E-mailing nepatrí k novým nástrojom marketingovej komunikácie, ale $\mathrm{s}$ nástupom pokročilých moderných technológií prináša vel’a nových možností. Newsletter je najviac rozšírenou podobou e-mailingu. Je to informačný e-mail, ktorý je rozosielaný v pravidelných intervaloch (napr. týždeň, mesiac), na ktorého odber sa spotrebitel' môže prihlásit'. Je vel'mi využívaným marketingovým prostriedkom aj v CR, môže obsahovat' napríklad informácie o súčasnom dianí, pripravovaných podujatiach a rôznych špeciálnych, napríklad limitovaných, ponukách (Dorčák, 2012). Túto formu marketingu nevyužíva mesto LM ani MAS HL. Pre záujemcov o takúto službu by mohlo mesto LM po príchode na internetovú stránku mesta alebo Facebook ponúknut' možnost' e-mailovej registrácie a následné zasielanie kalendária podujatí alebo mesačníka mesta na email užívatel'a. Podobný princíp marketingu je možné aplikovat' aj na územie MAS HL za predpokladu vytvárania mesačníka alebo iného on-line periodika, či propagačných materiálov.

Dosah elektronických marketingových stratégií závisí od viacerých faktorov, napr. od výberu kl'účových slov ako aj vel'kosti publika v danej oblasti a konkurencie, od ktorej sa následne odvíja aj cena zvolenej propagácie (cena za kliknutie na reklamu alebo cena podl'a počtu zobrazení danej reklamy). 
Efektivitu/dosah jednotlivých marketingových nástrojov možno jednoducho sledovat' prostredníctvom webových nástrojov, napr. Google Keyword Planner (www.ads.google.com/home/tools/keyword-planner/) alebo priamo v rozhraní Google Ads (www.ads.google.com). Využit' by bolo potenciálne možné aj sledovanost' (lokálnej) televízie či využivanie mobilnej aplikácie.

\section{Záver}

Za posledné desat'ročie prešiel marketing $\mathrm{v}$ dôsledku technologických zmien dramatickou zmenou. Najmä vd'aka rozvoju internetu sa marketingové stratégie CR museli prispôsobit' požiadavkám informačného veku. Od marketingu CR v regiónoch, mestách či obciach sa očakáva, že dostane tieto lokality do povedomia verejnosti, prispeje $\mathrm{k}$ ich presadeniu na trhu CR a zlepší imidž územia, čo zabezpečí ich rozvoj a prosperitu. Dôležitú úlohu v upevňovaní pozície na trhu zohráva $\mathrm{V}$ súčasnom období zostrenej konkurencie práve marketingová komunikácia. Jej vplyv odzrkadluje aj situácia na území mesta LM a MAS HL. Napriek spoločným predpokladom t'ažit' z CR možno pozorovat' na jednej strane rozvoj a zvýšenú zaangažovanost' sa v CR (mesto LM), na strane druhej postupnú stagnáciu na území MAS HL. Združenie by malo zastrešovat rozvojové požiadavky všetkých členských obcí, vytvárat' stratégie ich rozvoja, aktívne propagovat' územie využívaním marketingových trendov a zaradit' CR medzi priority v oblasti rozvoja územia. Sme toho názoru, že využitím nových trendov v marketingu a $\mathrm{v}$ marketingovej komunikácii by ako dôsledok náučno-informačných marketigových stratégií (obsahový, zážitkový, video marketing alebo lovemarks) došlo k postupnému rozvoju CR, k zlepšeniu poskytovaných služieb ako aj $\mathrm{k}$ posilneniu pozitívneho vzt’ahu človeka s krajinou.

\section{Pod'akovanie}

Príspevok bol spracovaný v rámci projektu VEGA č. 1/0496/16 - Hodnotenie prírodného kapitálu, biodiverzity a ekosystémových služieb na Slovensku - základ pre uplatňovanie integrovanej environmentálnej politiky $v$ prax.

\section{Literatúra}

ANDREOPOULOU, Z. - TSEKOUROPOULOS, G. - KOLIOUSKA, CH. KOUTROUMANIDIS, T. 2014. Internet marketing for sustainable development and rural tourism. In Business information systems. ISSN 17460980, 2014, vol. 16, no. 4. pp. 446-461.

BERESECKÁ, J. 2012. Zlepšenie efektívnosti marketingových prístupov k rozvoju vidieckeho cestovného ruchu v Nitrianskom kraji [Doktorská dizertačná práca]. Nitra: UKF v Nitre, 2012. 176 s. 
ČAKLOŠ, J. 2017. Čo je content marketing. [cit. 2018-08-14]. Dostupné na internete: <https://www.texto.sk/blog/co-je-content-marketing/>.

DORČÁK, P. 2012. eMarketing - ako oslovit' zákazníka na internete. Prešov: EZO, 2012. 180 s. ISBN 978-80-970564-4-5.

ELIÁŠ, P. 2010. Ekosystémové služby. In Životné prostredie. ISSN 0044-4863, 2010 , roč. 44 , č. 2 , s. 57-58.

GETZNER, M. - ŠSVAJDA, J. 2015. Preferences of tourists with regard to changes of the landscape of the Tatra National Park in Slovakia. In Land Use Policy. ISSN 0264-8377, 2015, vol. 48, pp. 107-119.

GÚČIK, M. - BURANOVSKÝ, J. - KRAUSOVÁ, T. - MALACHOVSKÝ, A. MARÁKOVÁ, V. - POMPUROVÁ, K. - RAŠI, Š. - SMUTNÁ, E. ŠČEPKOVÁ, E. 2011. Marketing cestovného ruchu. Banská Bystrica: SlovakSwiss Tourism, 2011. 264 s. ISBN 978-80-89090-85-3.

JAKUBÍKOVÁ, D. 2012. Marketing v cestovním ruchu. Praha: Grada Publishing, 2012. 320 s. ISBN 978-80-247-4209-0.

KUFČÁK, E. (ed.). 1968. Liptovský Mikulášs. Banská Bystrica: Stredoslovenské vydavatel'stvo. 1968.

KRAMÁREKOVÁ, H. - DUBCOVÁ, A. - OREMUSOVÁ, D. - HUSLICA, K. 2018. Budovanie značky regionálneho produktu v mikroregióne Cedron Nitrava. In Klímová, V., Žitek, $V$. (eds.) XXI. mezinárodní kolokvium o regionálních vědách. Sborník př́spěvkü. Brno: Masarykova univerzita, 2018. pp. 514 - 520. ISBN 978-80-210-8969-3.

KROGMANN, A. - NEMČÍKOVÁ, M. 2014. Quo vadis tourism in Nitra city? In Pachrová, S., Doležalová, M., Šip, J. (eds.) 9th International conference on topical issues of tourism - tourism and its impacts on society. Sbornik př́spěvků. Jihlava: Vysoká škola polytechnická, 2014. pp. 113-118. ISBN 97880-87035-87-0.

KROGMANN, A - NEMČÍKOVÁ, M. - OREMUSOVÁ, D. - VESELOVSKÝ, J. - ŠOLCOVÁ, L. - AMBROSIO, V. 2016. Religiózny cestovný ruch v meste Levoča. In Region v rozvoji společnosti : sbornik ze 7. ročníka mezinárodni vědecké konference. Brno: Mendelova univerzita, 2016. pp. 508-518. ISBN 978-80-7509-459-9.

LIN, Y. - HUANG, J. 2006. Internet blogs as a tourism marketing medium. In: Journal of Business Research. ISSN 0148-2963, 2006, vol. 59. no. 10-11, pp. 1201-1205.

MDV SR. 2013. SACR marketingová stratégia. [cit. 2018-08-14]. Dostupné na: <https://www.mzv.sk/documents/10182/12330/131218_Rada_131023_SACR_ marketingova_strategia.pdf/5896a8ce-a8a2-4543-ba40-78b490b5fe 29>.

MDV SR. 2018. Organizačný poriadok. [cit. 2018-08-14]. Dostupné na internete: <https://www.mindop.sk/ministerstvo-1/urad-ministerstva-5163/dokumenty-61/ organizacny-poriadok-208/organizacny-poriadok-platny-k-1-6-2018-pdf-1-5mb-974>. 
MIESTNA AKČNÁ SKUPINA HORNÝ LIPTOV. 2015a. Stratégia CLLD do roku 2020. [cit. 2018-08-14]. Dostupné na internete: <https://www.enviroportal.sk/eia/dokument/237031>.

MIESTNA AKČNÁ SKUPINA HORNÝ LIPTOV. 2015b. SPRO HL do roku 2022. [cit. 2018-08-14]. Dostupné na internete: <http://www.hornyliptov.sk/ upload/File/2016_dokumenty/SPRO_HL_19_4_2016.pdf >.

MSÚ LIPTOVSKÝ MIKULÁŚ. 2015. PHSR mesta Liptovský Mikuláš 2015 2022. [cit. 2018-08-14]. Dostupné na internete: <http://www.mikulas.sk/filesII/ prilohy/ PHSR_DOKUMENT_FINAL_28_12.pdf >.

NEMČÍKOVÁ, M. - KROGMANN, A. - DUBCOVÁ, A. 2016. Značka územia ako impulz regionálneho rozvoja na Slovensku. In Klímová, V., Žitek, V. (eds.). XIX. mezinárodni kolokvium o regionálnich védách. Sborník př́spěvků. Brno: Masarykova univerzita, 2016. pp. 832-838. ISBN 978-80-210-8273-1.

PALATKOVÁ, M. 2006. Marketingová strategie destinace cestovního ruchu. Praha: Grada Publishing, 2006. 341 s. ISBN 802-47-101-45.

PALENČÍKOVÁ, Z. - HRUBALOVÁ, L. 2016. Vnímanie mesta Nitra návštevníkmi. In Aktuálni problémy cestovního ruchu "Místni bohatstvi a cestovni ruch", Jihlava, 2016. s. 315-234. ISBN 978-80-88064-21-3.

POVAŽAN, R. 2013. Rekreačné hodnoty NP Vel'ká Fatra. In Acta Universitatis Matthiae Belii, séria Envirnomentálne manažérstvo. ISSN 1338-449X, 2013, roč. 15 , č. 1, s. 82-94.

RATHORE, A. - JOSHI, U. - ILAVARASAN, P. 2017. Social media usage for tourism: A case of Rajasthan Tourism. In Procedia Computer Science. ISSN 1877-0509, 2017, vol. 122, no. 1, pp. 754-758.

REGIÓN ŽILINA, 2018. Rozvojové dokumenty. [cit. 2018-08-14]. Dostupné na internete: 〈http://www.regionzilina.sk/sk/rozvojove-dokumenty-zsk/>.

ŠÚ SR, 2018. Stav a pohyb obyvatel’stva. [cit. 2018-08-14]. Dostupné na internete: $<$ http://datacube.statistics.sk/>.

TIGYI, M. 2016. Propagácia ako nástroj marketingu miestnej akčnej skupiny Regionálne združenie Dolná Nitra o.z. In Študentská vedecká konferencia 2015. Nitra: UKF v Nitre, 2016. ISBN 978-80-558-0791-1.

UNGR, P. - PENKALA, J. - KRKOŠKA, M. - JAŠEK, P. - NOTTINGHAM, P. 2014. Online marketing: Současné trendy očima predních expertů. 1. vyd. Brno: Computer Press, 2014. ISBN 978-80-251-4155-7.

VRBIČANOVÁ G. - KRAMÁREKOVÁ, H. 2016. Aktuálne trendy regionálneho rozvoja Miestnej akčnej skupiny Horný Liptov. In Geografické informácie. ISSN 1337-9453, 2016, roč. 20, č. 2, s. 768-781.

ZÁKON č. 91/2010 Z. z. o podpore cestovného ruchu

ZÁKON č. 281/2001 Z. z. o zájazdoch, podmienkach podnikania cestovných kancelárií a cestovných agentúr.

WANG, Y. - YU, Q. - FESENMAIER, D. R. 2002. Defining the virtual tourist community: implications for tourism marketing. In International Journal of 
Tourism Management. ISSN 0261- 5177, 2002, vol. 23, no. 4, pp. 407-417. WEISS, P. - JANKOVIČOVÁ, M. - KURČOVÁ, E. - KOSTOVSKÝ, D. VANÍČEK, M. 2005. Regionalizácia cestovného ruchu v Slovenskej republike. Bratislava: Ministerstvo hospodárstva SR, 2005. 114 s.

XIANG, Z. - GRETZEL, U. 2010. Role of social media in online travel information search. In Tourism Management. ISSN 0261-5177, 2010. vol. 31, no. 1. pp. 179-188.

\section{TOURISM MARKETING OF THE TOWN OF LIPTOVSKÝ MIKULÁŠ AND MUNICIPALITIES OF THE LOCAL ACTION GROUP HORNÝ LIPTOV - ITS REALITY AND POTENTIAL}

\section{Summary}

Over the last decade, marketing has gone through a dramatic change due to technological changes. Especially, thanks to the development of the Internet, tourism marketing strategies had to adapt to the requirements of the information age. The tourism marketing in regions, cities or municipalities is expected to bring these sites to public awareness, contribute to their promotion on the tourism market and improve the image of the territory which will ensure their development and prosperity. In the present time of intensified competition, an important role in the consolidation of the market position is played by marketing communication. Its impact reflects also the situation in the town of Liptovský Mikuláš (LM) and in the Local Action Group Horný Liptov (LAG HL). In spite of these predispositions, there are exacerbated differences in marketing and its marketing communication between the town and LAG HL. Despite of their common predispositions to benefit from tourism, we can observe the development and increased involvement in tourism in the town and, on the other hand, there is gradual stagnation in the LAG HL. The association should cover the development needs of all member municipalities, develop strategies for their development, actively promote the territory through the use of marketing trends and integrate tourism among the territorial developmental priorities. We believe that the usage of new trends in marketing and marketing communications - informational marketing strategies (contentual, experiential, video marketing or lovemarks) could result in gradual development of tourism, improvement of tourism services provided and creation of positive relationship between man and nature.

\section{Mgr. Gréta Vrbičanová}

Katedra ekológie a environmentalistiky FPV UKF v Nitre

Trieda A. Hlinku 1, 94974 Nitra

E-mail: greta.vrbicanova@ukf.sk 


\section{RNDr. Hilda Kramáreková, PhD.}

Katedra geografie a regionálneho rozvoja FPV UKF v Nitre

Trieda A. Hlinku 1, 94974 Nitra

E-mail: hkramarekova@ukf.sk 